\title{
Fertility and 305-day production of Viking Red-, Montbéliarde-, and Holstein-sired crossbred cows compared with Holstein cows during their first 3 lactations in Minnesota dairy herds
}

A. R. Hazel,, ${ }^{*}$ B B. J. Heins, (1) and L. B. Hansen $(1)$

Department of Animal Science, University of Minnesota, St. Paul 55108

\begin{abstract}
Three generations of crossbred cows from a 3-breed rotation of the Viking Red (VR), Montbéliarde (MO), and Holstein (HO) breeds were compared with $\mathrm{HO}$ herdmates in 7 high-performance, commercial dairy herds in Minnesota. The designed study was initiated in 2008 with the enrollment of 3,550 HO females. Sires of cows were proven artificial insemination bulls and were high-ranking for genetic merit within each of the $\mathrm{VR}, \mathrm{MO}$, and $\mathrm{HO}$ breeds. The first generation of cows calved a first time from 2010 to 2017 and consisted of $644 \mathrm{VR} \times \mathrm{HO}$ and $616 \mathrm{MO} \times \mathrm{HO}$ 2-breed crossbreds and their 1,405 HO herdmates. The second generation calved a first time from 2012 to 2017 and consisted of $615 \mathrm{VR} \times \mathrm{MO} / \mathrm{HO}$ and $568 \mathrm{MO} \times \mathrm{VR} / \mathrm{HO}$ crossbreds and their 1,462 HO herdmates. The third generation calved a first time from 2014 to 2017 and was composed of $466 \mathrm{HO} \times \mathrm{VR} / \mathrm{MO} / \mathrm{HO}$ and $\mathrm{HO} \times \mathrm{MO} / \mathrm{VR} /$ HO crossbreds combined and their $736 \mathrm{HO}$ herdmates. Collection of data ceased on December 31, 2017, and for the duration of study, many of the 2-breed and 3 -breed crossbreds and their HO herdmates had the opportunity to complete at least 3 lactations, whereas the HO-sired crossbreds and their HO herdmates had the opportunity to complete 1 lactation. The 305-d actual (not mature equivalent) production of milk, fat, and protein was estimated from test-day observations with best prediction and cows with $<305$ DIM were projected to $305 \mathrm{~d}$. The 2-breed and 3-breed crossbred cows had superiority over their HO herdmates for all of the fertility traits measured. The 2-breed crossbreds had $-9,-17$, and $-15 \mathrm{~d}$ fewer days open than their HO herdmates during first, second, and third lactation, respectively. Also, the 3 -breed crossbreds had
\end{abstract}

Received January 13, 2020.

Accepted April 22, 2020.

*Corresponding author: haze0025@umn.edu
$-15,-19$, and $-20 \mathrm{~d}$ fewer days open than their HO herdmates during first, second, and third lactation, respectively. Cows in these herds had young ages at first calving of 22 to 23 mo across the breed groups, and the 3-breed crossbreds had significantly younger ages at first, second, and third calving than their $\mathrm{HO}$ herdmates. The 2-breed crossbreds had $+2 \%$ higher fat plus protein production $(\mathrm{kg})$ during first lactation, but did not differ during second and third lactation, from their HO herdmates. The 3 -breed crossbreds had $-3 \%$ to $-4 \%$ lower fat plus protein production $(\mathrm{kg})$ than their HO herdmates in each of their first 3 lactations. During first lactation, the HO-sired crossbreds did not differ for fat plus protein production $(\mathrm{kg})$ from their HO herdmates.

Key words: crossbreeding, fertility, Montbéliarde, Viking Red

\section{INTRODUCTION}

The opportunity for improvement of fertility of dairy cattle is a major reason for interest in crossbreeding by dairy producers because fertility has substantial economic consequences (Inchaisri et al., 2010). A longterm decline in fertility of dairy cows, particularly the global Holstein (HO) breed, exists for many diverse production systems (Walsh et al., 2011). In the United States, the Council on Dairy Cattle Breeding (CDCB, 2019) reported phenotypic fertility of $\mathrm{HO}$ cows declined substantially between 1960 and 2000; however, dairy producers have made meaningful phenotypic improvement in fertility, equivalent to $29 \mathrm{~d}$ fewer days open (DO), for HO cows born between 2000 and 2015. A small amount of the phenotypic improvement was the result of genetic improvement because the Council on Dairy Cattle Breeding (CDCB, 2019) reported breeding values for $\mathrm{DO}$ of cows increased by only $2.7 \mathrm{~d}$ for HO cows born between 2009, the year of lowest breeding value for DO, and 2015. Instead, improved cow facilities, enhanced usage of ovulation synchronization or activity monitoring systems, and the reduced usage of 
bST (Shibru, 2016) are potential reasons for phenotypic fertility improvements.

Heritability estimates for fertility traits are low compared with other traits under selection for dairy cattle. Fleming et al. (2019) summarized the heritability estimates for fertility from countries participating in the Interbull Bull Evaluation Service (Interbull, Uppsala, Sweden). Fleming et al. (2019) reported the heritability for conception rate (CR) of lactating cows ranged from 0.01 to 0.07 and for DO ranged from 0.01 to 0.08 . Furthermore, the same authors reported the relative emphasis on fertility traits in selection indices globally was $14.8 \pm 1.51 \%$ (Fleming et al., 2019). Therefore, dairy producers should not expect rapid genetic improvement for fertility traits of HO cows during the relatively few years that fertility has been included in selection goals, because of the low selection emphasis on fertility in many countries.

Some dairy producers have turned to crossbreeding because the estimated heterosis of $10 \%$ for fertility traits (VanRaden et al., 2004; Sørensen et al., 2008) is high compared with most other traits, such as production, and has essentially an equal and opposite effect to inbreeding depression (Falconer and Mackay, 1996). Therefore, a larger response in phenotypic fertility will be experienced over a shorter period of time from crossbreeding than from selection within a pure HO population (Buckley et al., 2014) for 3 reasons: (1) other dairy breeds are genetically superior to $\mathrm{HO}$ for female fertility, (2) other dairy breeds may experience a more rapid rate of genetic improvement for fertility with time, and (3) the gain from heterosis eliminates concern about inbreeding depression because the mean inbreeding coefficient for $\mathrm{HO}$ females has increased at an unprecedented rate $(+0.35 \%$ annually) in the United States during the most recent 5 yr according to the Council on Dairy Cattle Breeding (http://queries .uscdcb.com/eval/summary/inbrd.cfm).

Heterosis for production traits is about $3 \%$ when unrelated breeds are crossed (Sørensen et al., 2008; Jönsson, 2015) and is lower than heterosis for fertility, survival, and health. However, heterosis for fat and protein production $(\mathrm{kg})$ is adequate for crossbreds to have fat and protein production $(\mathrm{kg})$ that is similar to $\mathrm{HO}$ cows in high-production, confinement environments, provided the breeds chosen have high production potential with a competitive genetic trend for production.

The rotation of the Viking Red (VR), Montbéliarde (MO), and HO breeds for crossbreeding is marketed as ProCROSS by Viking Genetics (Randers, Denmark) and Coopex Montbéliarde (Roulans, France) and has experienced heightened interest by dairy producers globally. The VR breed is the result of a combined breeding program of the formerly separate Swedish Red, Danish Red, and Finnish Ayrshire breeds. The fertility and production performance of VR-sired and MO-sired crossbreds have been compared with $\mathrm{HO}$ cows in recent research (Heins and Hansen, 2012; Malchiodi et al., 2014; Dezetter et al., 2015; Jönsson, 2015; Clasen et al., 2019). These studies each had one or more shortcomings because (1) they compared VRsired and MO-sired crossbreds to HO cows either from field studies or from national data that lacked a balanced experimental design for breed groups, (2) they included a small number of cows or herds, or (3) they failed to analyze the performance of cows beyond the first generation of crossbreeding.

The objective of this research was to analyze phenotypes of cows for fertility and 305-d production $(\mathrm{kg})$ of both $\mathrm{VR} \times \mathrm{HO}$ and $\mathrm{MO} \times \mathrm{HO}$ 2-breed crossbreds as well as $\mathrm{VR} \times \mathrm{MO} / \mathrm{HO}$ and $\mathrm{MO} \times \mathrm{VR} / \mathrm{HO} 3$-breed crossbreds compared with their HO herdmates during their first 3 lactations in high-input, commercial herds that resulted from a designed mating plan. Furthermore, the phenotypes of HO-sired crossbreds in the subsequent generation were compared with their HO herdmates for only the first lactation. The thirdgeneration crossbreds calved during the last $3 \mathrm{yr}$ of the 10-yr study, and therefore, insufficient numbers of lactations of cows beyond first lactation were available for analysis.

\section{MATERIALS AND METHODS}

\section{Experimental Design}

Description of Herds and Cows. A 10-yr study was initiated in 2008 to compare phenotypic groups of 3-breed rotational crossbred cows with their $\mathrm{HO}$ herdmates, and the first-lactation results from the first generation of the study were previously reported by Hazel et al. (2017a,b). Pure HO females in 8 Minnesota dairy herds were enrolled as the "foundation" generation of cows from March, 2008, to September, 2008. The herds were collectively elite in regard to production and overall management. Although the herds had very high mean production, the dairy producers chose to participate in the study because they sought to improve the health and fertility of cows and to decrease labor costs. Furthermore, some of the dairy producers had previous experience with milking some crossbred cows in their herds. The 8 herds were located in southeastern, southwestern, and central Minnesota, and cows were housed in 4-row or 6-row confinement, freestall facilities with a TMR fed to all lactating cows. Stalls were either bedded with deep sand ( 5 herds), mattresses with 
sawdust ( 1 herd), a combination of those ( 1 herd), or manure solids (1 herd). In 2016, 2 of the herds with the same owner were combined into a single facility. Those 2 dairy herds had shared feed resources and management during the first $8 \mathrm{yr}$ of the study; therefore, all data from these 2 herds were combined across the years of the study for analysis. Consequently, 7 herds were available for analysis.

The foundation HO females that were enrolled across all of the herds included 3,550 females and most of them were nulliparous, first-lactation, or second-lactation cows when enrolled. Each dairy producer committed a minimum of 250 foundation HO heifers and cows; however, the herd with the largest enrollment committed 785 foundation females. Throughout the years of the study, the dairy producers managed cows in the breed groups the same in all ways. They comingled heifers and cows without regard to breed group and used identical protocols within herd for insemination, health treatment, and culling. Heifers and cows were grouped by age, stage of lactation, or reproductive status across breed groups.

Mating Design and Sire Selection. Heifers and cows enrolled in the study were paired for assignment to be mated by AI to either VR or MO bulls for initiation of 3-breed rotational crossbreeding or mated to HO bulls for ongoing purebreeding. For the crossbred group, the resulting 2-breed progeny $(\mathrm{VR} \times \mathrm{HO}$ and $\mathrm{MO} \times \mathrm{HO}$ crossbreds) were mated by $\mathrm{AI}$ to the third breed (i.e., $\mathrm{VR} \times \mathrm{HO}$ crossbreds were mated to $\mathrm{MO}$ and the $\mathrm{MO} \times \mathrm{HO}$ crossbreds were mated to $\mathrm{VR}$ bulls). In the subsequent generation, those resulting 3 -breed crossbreds of both types were mated by AI to HO bulls to create HO-sired crossbreds. The HO-sired crossbreds were mated to the breed of their maternal great-grandsire. Meanwhile, the foundation $\mathrm{HO}$ cows that were mated by AI with $\mathrm{HO}$ bulls produced $\mathrm{HO}$ herdmates for comparison with the crossbred cows, and the $\mathrm{HO}$ cows were mated by $\mathrm{AI}$ to $\mathrm{HO}$ bulls in subsequent generations to maintain a continuous HO comparison group in each herd.

Within each herd, a minimum of 100 foundation $\mathrm{HO}$ females were mated for crossbreeding and a minimum of 150 foundation females were mated for purebreeding. However, dairy producers who enrolled additional foundation females above 250 were allowed to choose to which breed group (crossbred or HO) the additional females would be assigned. Across the 7 herds, $56 \%$ of foundation HO females were mated by AI with VR or MO bulls (and exactly half to each breed) and the other $44 \%$ were mated by AI with $\mathrm{HO}$ bulls. Heifers and cows were paired for assignment to breed groups by University of Minnesota researchers and were balanced by age and sire for heifers and lactation number, sire, and projected mature-equivalent milk production for cows.

All heifers and cows were individually mated by 2 genetic advisors employed by Minnesota Select Sires Co-op Inc. (St. Cloud, MN). Both crossbred and HO cows were correctively mated for conformation, and nulliparous heifers were correctively mated based on conformation scores of their dams when possible. Furthermore, inbreeding protection was provided when $\mathrm{HO}$ females were mated to HO bulls.

Proven AI bulls were mated to heifers and cows for all 3 breeds across all generations of the study and were selected by the dairy producers with consultation by the 2 genetic advisors. All matings were with conventional, unsexed semen for both heifers and cows. Semen for the VR and MO bulls was imported to the United States by Creative Genetics of California (Oakdale, CA) and ranked highly among bulls available in the United States for the Nordic Total Merit index (http:// nordicebv.info/ntm-nordic-total-merit-2) or the French ISU index (http://montbeliarde.org/en-428.html), which are the national selection indices for the VR and MO breeds, respectively. The HO bulls were all marketed by Select Sires Inc. (Plain City, $\mathrm{OH}$ ), and dairy producers were asked to use bulls that ranked among the top $10 \%$ of available bulls for the Net Merit Index (VanRaden et al., 2018) at the time of selection. Some dairy producers in the study mated some cows to beef breed bulls, natural service bulls, or unproven AI bulls for fifth and later inseminations of cows within a lactation. Additionally, a small number of inseminations before fifth insemination were not based on the prescribed matings. However, progeny resulting from these circumstances were not included in the study.

Initial Data Editing. The foundation generation of HO cows gave birth from January 2009 to August 2015 to $\mathrm{VR} \times \mathrm{HO}$ and $\mathrm{MO} \times \mathrm{HO}$ 2-breed crossbreds and their HO herdmates. The numbers of heifers available that were not stillborn nor born twin to a bull calf are in Table 1. A total of 422 heifers left the herds before a first calving and, therefore, were not available to be included in the analyses of fertility traits nor 305-d production $(\mathrm{kg})$. All of the 2-breed crossbreds and their $\mathrm{HO}$ herdmates had a first calving before the end of data collection, which was December 31, 2017. As a result, 1,260 2-breed crossbreds and 1,405 HO herdmates from the 7 herds combined remained for analysis.

The 3-breed crossbreds were born from January 2011 to October 2015 (Table 1). The edits removed 506 heifers that left the herds before first calving, and also $1 \%(\mathrm{n}=37)$ of the 3 -breed crossbreds and their HO herdmates that were at least 26 mo of age but had not 
yet calved or had not left the herd by the end of data collection. Therefore, 1,183 of the 3-breed crossbreds and 1,462 $\mathrm{HO}$ herdmates remained for analysis and calved a first time from November 2012 to December 2017.

The final group compared for this study was the HO-sired crossbreds and their HO herdmates (Table 1). These heifer calves were born from September 2012 to October 2015. A total of 253 heifers left the herds before first calving. Another 3\% $(\mathrm{n}=52)$ of heifers were removed from analysis because they were $>26$ mo of age and had not yet calved or had not left the herd by the end of data collection. Therefore, $466 \mathrm{HO}$-sired crossbreds and $736 \mathrm{HO}$ herdmates remained for analysis and calved a first time from June 2014 to December 2017. For all 3 generations of crossbreds and their HO herdmates that were analyzed in this study, the proportion of nulliparous females that left the herds before first calving cannot be interpreted as a survival rate during the heifer period because many of these heifers across both breed groups were sold for dairy purposes.

Cows that initiated lactation with an abortion were removed from analysis for all fertility and 305-d production traits. Days of gestation $<260 \mathrm{~d}$ were considered an abortion, and across the 3 generations studied, 59 crossbreds and $61 \mathrm{HO}$ herdmates were removed for the first-lactation analysis, but were potentially included for analysis of subsequent lactations. For second and third lactation, data from 65 crossbred and $52 \mathrm{HO}$ herdmates and 52 crossbred and $34 \mathrm{HO}$ herdmates were removed, respectively, from analysis.

\section{Trait Descriptions}

Fertility. First-service conception rate (FSCR) was the proportion of first inseminations that resulted in pregnancy divided by all first inseminations within a lactation. The overall CR was the proportion of successful inseminations divided by all inseminations within a lactation, but only the first 5 inseminations per lactation were considered. For both FSCR and overall CR, conception was confirmed by ultrasound, palpation, or a subsequent insemination, and was verified by a subsequent calving when possible. Also, only inseminations $\geq 45$ DIM and $\leq 305$ DIM were included to remove potential bias from preferential treatment of individual cows.

The times bred was the total number of inseminations per lactation for an individual cow. Cows with more than 5 inseminations in a lactation were set to a maximum of 5 inseminations. The final fertility trait was DO, which was defined as the number of $\mathrm{d}$ from calving to conception. Cows with DO $<50$ were set to $50 \mathrm{DO}$ and cows with $>250 \mathrm{DO}$ were set to $250 \mathrm{DO}$, which is the same procedure used by the Council on Dairy Cattle Breeding for fertility evaluations in the United States. Only cows with calving dates before April 26, 2017, were included for times bred and for DO to ensure cows had at least $250 \mathrm{~d}$ of opportunity before the end of data collection (December 31, 2017).

Age at Calving and 305-d Production. Age in months at first, second, and third calving was calculated from calving and birth dates available in Dairy

Table 1. Edits for crossbreds and their Holstein (HO) herdmates

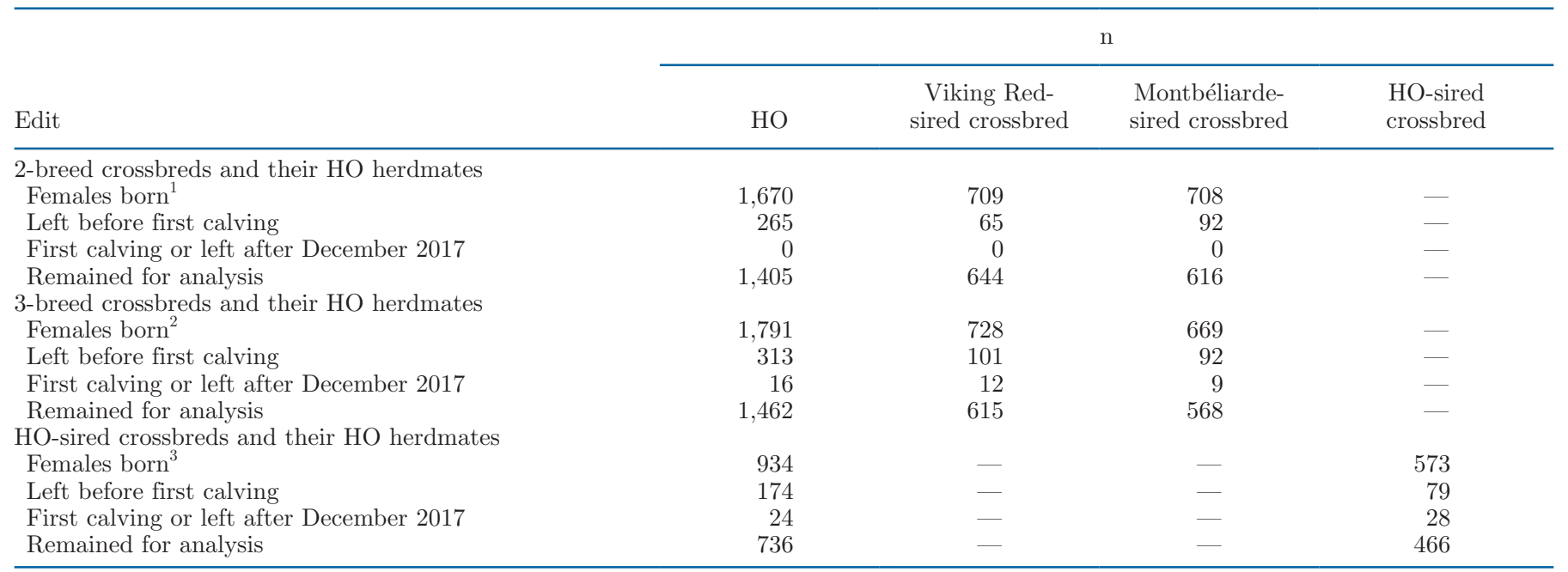

${ }^{1}$ Females with opportunity to calve for a first time from December 2010 to December 2017.

${ }^{2}$ Females with opportunity to calve for a first time from November 2012 to December 2017.

${ }^{3}$ Females with opportunity to calve for a first time from December 2014 to December 2017. 
Comp 305 software (Valley Agricultural Software, Tulare, CA). The 305-d milk, fat, and protein production $(\mathrm{kg})$ were calculated from test-day observations from milk recording (Minnesota DHIA, Buffalo, MN). The 7 herds participated in official DHI testing between 8 and 12 times annually for the 10-yr duration of the study. Individual test-day observations were required to have a milk, fat, and protein observation and were excluded if they had fewer than 4 DIM. Furthermore, test-day milk weight was required to be at least $4.54 \mathrm{~kg}$, fat percentage was required to be $\geq 1.0 \%$ and $\leq 9.0 \%$, and protein percentage was required to be $\geq 1.0 \%$ and $\leq 6.0 \%$.

The 305-d production (actual, not mature equivalent) was calculated using Best Prediction (BP; Cole et al., 2009), which is a program developed by the Animal Genomics and Improvement Laboratory of USDA (Beltsville, MD) for genetic evaluation of production for US dairy cattle. The BP adjusted lactational records to a constant age at calving for each lactation number. Cows with fewer than $305 \mathrm{~d}$ of actual production were projected to $305 \mathrm{~d}$. The BP was applied separately to each of the 7 herds. The BP used a 3-parameter Wood's curve with fixed regression coefficients for milk, fat, and protein production $(\mathrm{kg})$ for each lactation number. Regardless of breed group, all cows were estimated with the HO breed parameters because parameters for crossbred cows were not available. Fat plus protein production $(\mathrm{kg})$ was the sum of $305-\mathrm{d}$ fat $(\mathrm{kg})$ and $305-$ $\mathrm{d}$ protein $(\mathrm{kg})$ and was calculated individually for all lactations of cows.

All 7 herds routinely milked most cows 3 times daily throughout the study; however, some cows were milked twice daily during a small number of test days. A chisquared test revealed that the crossbreds $(3.4 \%)$ did not differ $(P=0.31)$ from $\mathrm{HO}$ cows $(3.2 \%)$ for the percentage of test days that were from 2 times daily milking. The BP adjusted test-day observations for milking frequency before estimation of 305-d milk, fat, and protein production $(\mathrm{kg})$.

\section{Final Editing and Analysis}

Fertility. The numbers of cows analyzed within each generation of crossbred cows and their HO herdmates as well as within lactation number differed for each of the 4 fertility traits because edits were applied independently for each trait. For FSCR, 1,066 lactations without a first insemination were removed, and another 95 lactations were removed for cows that left the herd before conception could be confirmed. A small number of cows were inseminated with AI bulls that were not from the correct breed prescribed in the study design, were inseminated with sexed semen, or were inseminated by a natural service bull. Those lactations ( $\mathrm{n}=451)$ were removed for analysis of FSCR, as were lactations $(\mathrm{n}=18)$ of cows with a first insemination before 45 DIM. Observations of cows remaining were assigned to herd-year-season (HYS) of calving within each lactation number, and HYS were defined as 4-mo periods (January to April, May to August, and September to December), which reflect the climatic conditions of Minnesota. The data were further edited to permit balanced comparison of crossbreds and their HO herdmates within each HYS, and this editing was done separately for each generation of crossbreds and HO herdmates and for each lactation number. Each HYS was required to contain 3 crossbreds and $3 \mathrm{HO}$ herdmates to remain in the data. For the analysis of 2-breed and 3-breed crossbreds and their respective $\mathrm{HO}$ herdmates, the HYS with $<3$ of each type of VR-sired or MO-sired crossbred were combined with the smallest adjacent HYS and the combining of up to 3 HYS (12mo period) was permitted.

The edits for overall $\mathrm{CR}$ were similar to those used for FSCR, and they included the removal of 1,066 lactations of cows without at least one insemination and the removal of another 95 lactations of cows that left the herd without confirmed conception on first insemination. Because CR may differ by insemination number, potential bias from in-progress lactations was accounted for by the removal of 749 lactations of cows with fewer than 250 DIM by the end of data collection. An additional 324 inseminations without confirmed conception were removed from data for overall CR. Similar to the edits for FSCR, inseminations of cows with AI bulls that were not from the prescribed breed in the study design, with sexed semen, or by a natural service bull were removed from the data. Also, the subsequent inseminations following these circumstances within the same lactation number $(\mathrm{n}=1,019)$ were removed from the data. Furthermore, inseminations of cows before 45 DIM $(\mathrm{n}=18)$ were removed from the data for overall CR. Lastly, the same procedures used to edit FSCR data for HYS of calving were applied to overall CR.

The edits for times bred removed 755 lactations of cows without $250 \mathrm{~d}$ of opportunity before the end of the data collection, 136 lactations of cows inseminated by natural service or sexed semen before sixth insemination, and 20 lactations of cows first inseminated before 45 DIM. For DO, the edits removed 1,296 lactations without $250 \mathrm{~d}$ of opportunity before the end of data collection and 155 lactations of cows inseminated by natural service bulls or inseminated with sexed semen before 250 DIM. Furthermore, lactations $(\mathrm{n}=1,592)$ of cows that did not complete 250 DIM were removed from the data. The same edits for HYS that were applied to 
the CR traits by generation and lactation number were applied to both times bred and DO. Following the HYS edits for times bred and DO for third-lactation 3-breed crossbreds, only one herd lacked the required minimum number of cows for a HYS for those 2 traits. Therefore, the results for third-lactation 3-breed crossbreds compared with their $\mathrm{HO}$ herdmates for times bred and DO included cows from 6 of the 7 herds.

The final number of cows analyzed for FSCR, overall $\mathrm{CR}$, times bred, and DO are shown by breed type and lactation number for 2-breed crossbreds and their $\mathrm{HO}$ herdmates, 3-breed crossbreds and their HO herdmates, and HO-sired crossbreds and their $\mathrm{HO}$ herdmates in Tables 2, 3, and 4, respectively. The numbers of cows analyzed in successive lactations within a breed type should not be interpreted to be survival to a subsequent lactation because the edits applied to the fertility traits may misrepresent the actual survival of cows. Furthermore, cows with lactations in progress at the end of data collection may not have had an opportunity to be analyzed for all traits or lactation numbers, and this was especially the case for the 3-breed crossbreds and $\mathrm{HO}$-sired crossbreds and their respective $\mathrm{HO}$ herdmates. Each generation of crossbreds and their HO herdmates were analyzed separately because the design of the study did not allow for lengthy periods of overlap between the 2-breed and 3-breed crossbreds nor between the 3-breed and HO-sired crossbreds. However, a small number of the HO herdmates of 2-breed crossbreds were also used as HO herdmates of 3-breed crossbreds, and likewise, few of the HO herdmates of 3-breed crossbreds were also HO herdmates of HO-sired crossbreds during first lactation.

The analysis of FSCR, overall CR, times bred, and days open for the 2-breed and 3-breed crossbreds compared with their HO herdmates included the fixed effects of lactation number (1 to 3 ), HYS nested within lactation number, breed group (crossbred or HO), sire breed nested within breed group (e.g., VR $\times$ HO nested within crossbred and henceforth referred to as breed type), the interaction of lactation number and breed group, and the interaction of lactation number and breed type. The effect of cow nested within breed type was considered to be a random effect. Furthermore, service sire nested within breed type was a random effect only for the analyses of FSCR and overall CR because both of these traits were analyzed for single inseminations, whereas times bred and DO were traits of cows that often included multiple inseminations. The MIXED procedure of SAS (release 9.4; SAS Institute Inc., Cary, $\mathrm{NC}$ ) was used to perform the ANOVA and obtain least squares solutions. The FSCR and overall CR were binary traits, and therefore, the GLIMMIX procedure of SAS was used to determine probability of significance

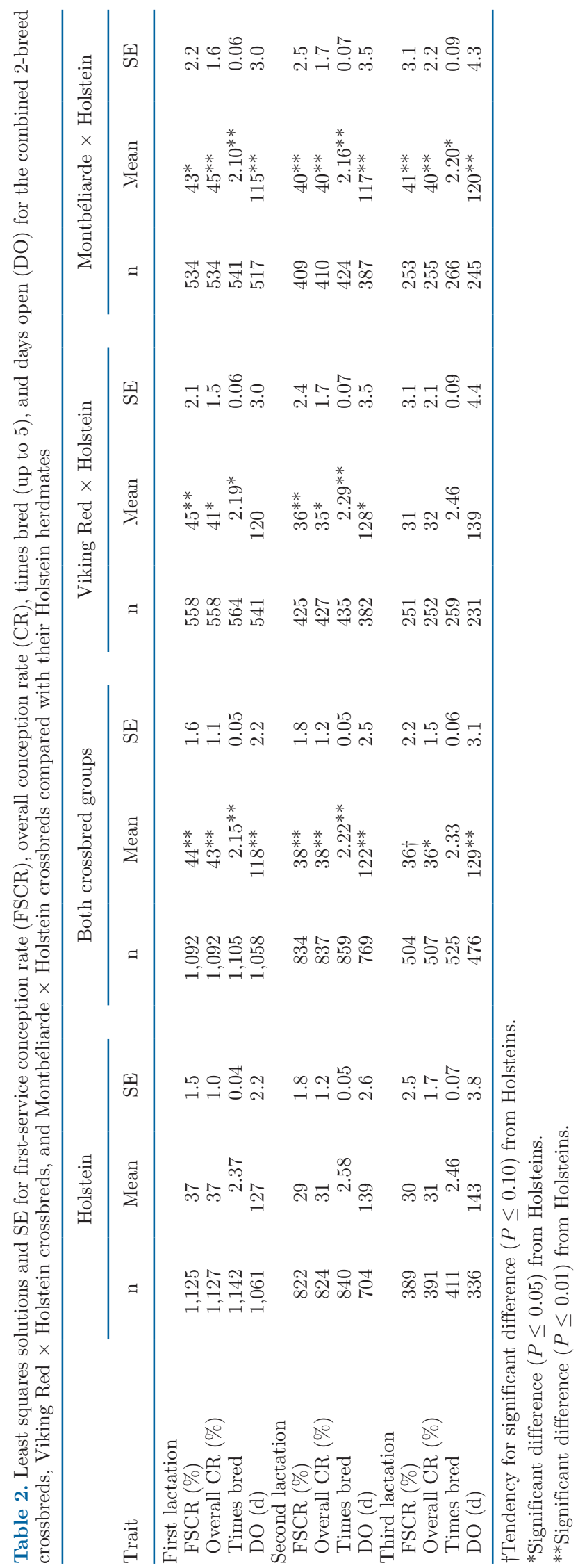




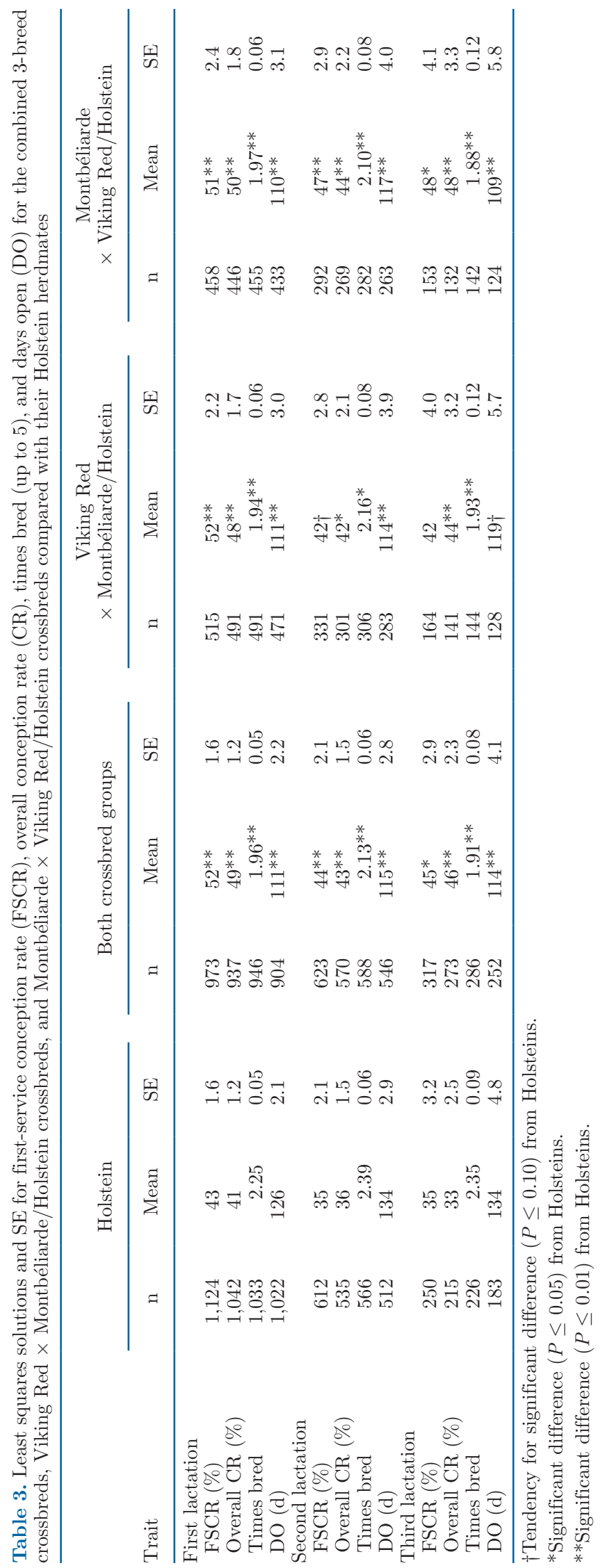

for contrasts between breed group and breed type for each lactation number. The statistical analysis of breed type (2-breed and 3-breed crossbreds compared with their respective HO herdmates) was subjected to the Bonferroni correction for multiple comparisons. Within lactation number, $\mathrm{HO}$ was designated to be the control to correct the $P$-values that compared each crossbred breed type with their HO herdmates.

The analysis of the HO-sired crossbreds compared with their HO herdmates was only for first lactations and all of the HO-sired crossbreds were considered to be a single breed type. Therefore, the independent variables for the analysis of all 4 fertility traits included only HYS of first calving and breed group (crossbred or HO). The effect of service sire nested within breed group was a random effect only for FSCR and overall CR. The MIXED procedure of SAS was used to perform the ANOVA and obtain least squares solutions, and the GLIMMIX procedure of SAS was used to determine significance of contrasts between breed groups for the analysis of FSCR and overall CR. The GLM procedure of SAS was used to perform the ANOVA and obtain least squares solutions for times bred and DO of the HO-sired crossbreds and their $\mathrm{HO}$ herdmates during first lactation.

Age at Calving and 305-d Production. Lactations of cows analyzed for age at calving were the same as those analyzed for 305-d production. Lactations of cows were required to have at least 2 test days for calculation of 305-d production, and as a consequence, 500 lactations of cows were removed. Also, lactations $(\mathrm{n}=$ 1,330) of cows that commenced after March 1, 2017, were removed because cows were required to have at least $305 \mathrm{~d}$ of opportunity to complete a lactation in progress before the end of the data collection. Edits on HYS of calving were the same for age at calving and 305-d production as those used for fertility traits and were performed independently for each generation and lactation number. Similar to 2 of the fertility traits, only 6 of the 7 herds contributed data for the analysis of production traits of third-lactation 3-breed crossbreds and their HO herdmates, because one herd did not have enough 3-breed crossbreds in third lactation to meet HYS requirements. The final numbers of observations analyzed for age at calving and 305-d production are included in Tables 5, 6, and 7 for the 2-breed, 3-breed, and HO-sired crossbreds, respectively, compared with their HO herdmates.

Age at calving was analyzed separately for each lactation number and for each of the 2-breed, 3-breed, and HO-sired crossbreds and their respective $\mathrm{HO}$ herdmates. The independent variables included in the analysis of age at calving were HYS of calving, breed group (crossbred or HO), and breed type (e.g., VR $\times$ 
Table 4. Least squares solutions and SE for first-service conception rate (FSCR), overall conception rate (CR), times bred (up to 5), and days open (DO) for the Holstein-sired crossbreds compared with their Holstein herdmates for first lactation

\begin{tabular}{lccccccc}
\hline & \multicolumn{3}{c}{ Holstein } & & \multicolumn{3}{c}{ Holstein-sired crossbred } \\
\cline { 2 - 4 } \cline { 6 - 8 } Trait & $\mathrm{n}$ & Mean & $\mathrm{SE}$ & & $\mathrm{n}$ & $\mathrm{N}$ Mean & \multirow{2}{*}{$\mathrm{SE}$} \\
\hline FSCR (\%) & 484 & 43 & 2.4 & & 305 & 46 & 3.0 \\
Overall CR (\%) & 421 & 42 & 1.9 & & 256 & 46 & 2.5 \\
Times bred & 428 & 2.23 & 0.07 & & 281 & 2.06 & 0.09 \\
DO (d) & 415 & 128 & 3.5 & & 274 & 121 & 4.3 \\
\hline
\end{tabular}

HO nested within crossbred), except breed type was not included for age at first calving of the HO-sired crossbreds and their HO herdmates. The GLM procedure of SAS was used to perform the ANOVA and to obtain least squares solutions. The $P$-values of contrasts between the 2-breed and 3-breed crossbred breed types and their HO herdmates were corrected with the Bonferroni adjustment.

The independent variables included in the analysis of 305-d milk, fat, protein, and fat plus protein production $(\mathrm{kg})$ of the 2-breed and 3-breed crossbreds compared with their respective HO herdmates included lactation number (1 to 3), HYS nested within lactation number, breed group (crossbred or HO), breed type (e.g., VR $\times$ HO nested within crossbred), interaction of lactation number and breed group, and the interac- tion of lactation number and breed type. The effect of cow nested within breed type was considered to be a random effect. The MIXED procedure of SAS was used to perform the ANOVA and to obtain least squares solutions. The Bonferroni adjustment was employed to correct the $P$-values of contrasts between the crossbred breed types and their $\mathrm{HO}$ herdmates within lactation number as was described for the fertility traits. Similar to the fertility traits, each of the 2-breed and 3-breed crossbreds and their respective $\mathrm{HO}$ herdmates were analyzed separately.

Similar to the fertility traits, all HO-sired crossbreds were considered a single breed type for the analysis of 305-d production $(\mathrm{kg})$. The analysis of the HOsired crossbreds and their HO herdmates during first lactation included the fixed effects of HYS and breed

Table 5. Least squares solutions and SE for age at calving and 305-d production (actual basis, not mature equivalent) for the combined 2-breed crossbreds, Viking Red $\times$ Holstein crossbreds, and Montbéliarde $\times$ Holstein crossbreds compared with their Holstein herdmates

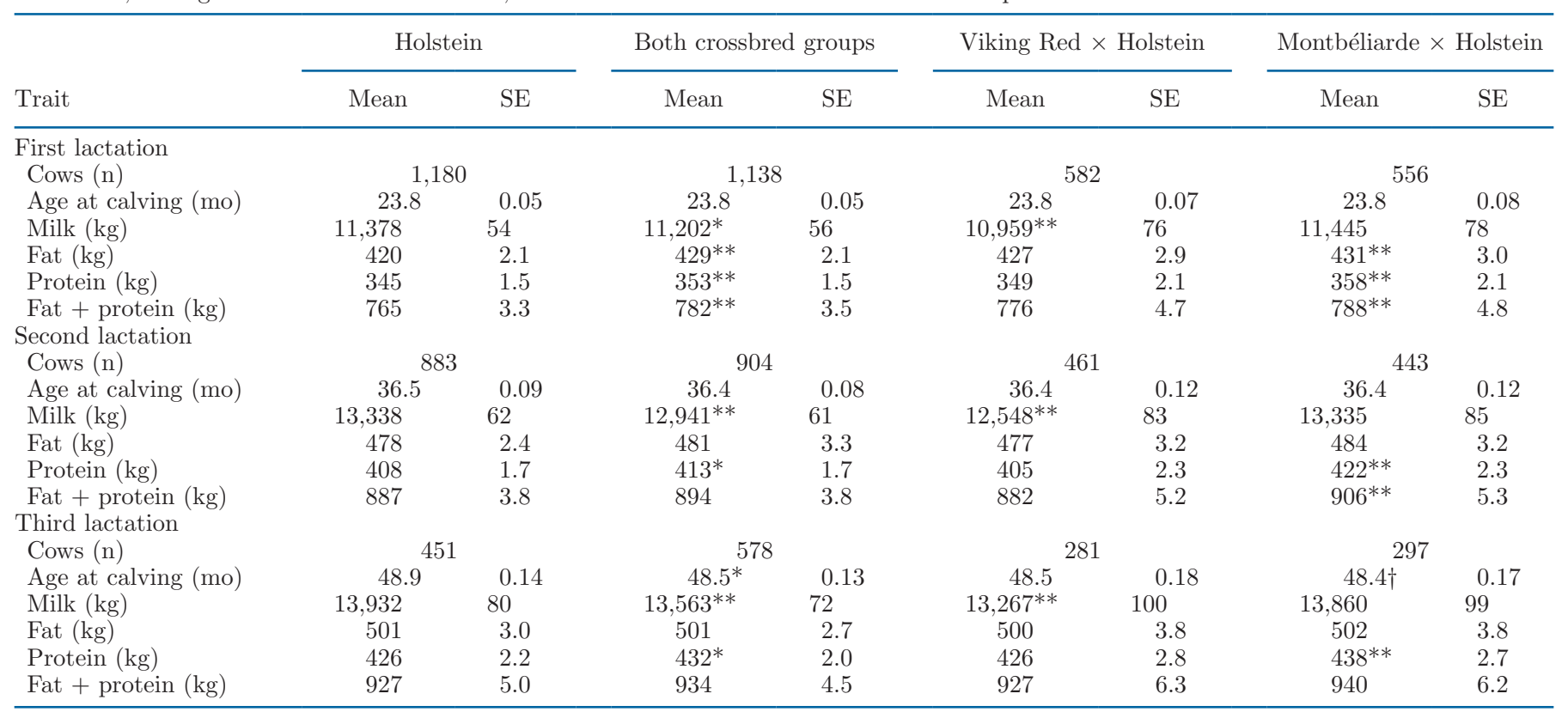

$\dagger$ Tendency for significant difference $(P \leq 0.10)$ from Holsteins.

*Significant difference $(P \leq 0.05)$ from Holsteins.

**Significant difference $(P \leq 0.01)$ from Holsteins. 
Table 6. Least squares solutions and SE for age at calving and 305-d production (actual basis, not mature equivalent) for the combined 3-breed crossbreds, Viking Red $\times$ Montbéliarde/Holstein crossbreds, and Montbéliarde $\times$ Viking Red/Holstein crossbreds compared with their Holstein herdmates

\begin{tabular}{|c|c|c|c|c|c|c|c|c|}
\hline \multirow[b]{2}{*}{ Trait } & \multicolumn{2}{|c|}{ Holstein } & \multicolumn{2}{|c|}{$\begin{array}{l}\text { Both crossbred } \\
\text { groups }\end{array}$} & \multicolumn{2}{|c|}{$\begin{array}{c}\text { Viking Red } \\
\times \text { Montbéliarde/Holstein }\end{array}$} & \multicolumn{2}{|c|}{$\begin{array}{c}\text { Montbéliarde } \\
\times \text { Viking Red/Holstein }\end{array}$} \\
\hline & Mean & $\mathrm{SE}$ & Mean & $\mathrm{SE}$ & Mean & $\mathrm{SE}$ & Mean & $\mathrm{SE}$ \\
\hline Cows (n) & \multicolumn{2}{|c|}{1,073} & \multicolumn{2}{|c|}{967} & \multicolumn{2}{|c|}{505} & \multicolumn{2}{|c|}{462} \\
\hline Age at calving (mo) & 23.2 & 0.05 & $22.8^{* *}$ & 0.05 & $22.7^{* *}$ & 0.07 & $22.9 *$ & 0.08 \\
\hline Milk (kg) & 11,803 & 58 & $10,736^{* *}$ & 60 & $10,601 * *$ & 82 & $10,871^{* *}$ & 85 \\
\hline \multicolumn{9}{|l|}{ Second lactation } \\
\hline Cows $(n)$ & \multicolumn{2}{|c|}{582} & \multicolumn{2}{|c|}{600} & \multicolumn{2}{|c|}{309} & \multicolumn{2}{|c|}{291} \\
\hline Age at calving (mo) & 35.9 & 0.10 & $35.2^{* *}$ & 0.10 & $35.0^{* *}$ & 0.14 & $35.3^{* *}$ & 0.14 \\
\hline Milk $(\mathrm{kg})$ & 13,551 & 73 & $12,463^{* *}$ & 73 & $12,225^{* *}$ & 99 & $12,701^{* *}$ & 102 \\
\hline Fat $(\mathrm{kg})$ & 492 & 2.7 & $470^{* *}$ & 2.7 & $463^{* *}$ & 3.7 & $476^{* *}$ & 3.9 \\
\hline Protein $(\mathrm{kg})$ & 415 & 2.0 & $406^{* *}$ & 2.0 & $399 * *$ & 2.8 & 413 & 2.9 \\
\hline \multicolumn{9}{|l|}{ Third lactation } \\
\hline Fat $(\mathrm{kg})$ & 517 & 4.1 & $486^{* *}$ & 3.8 & $479^{* *}$ & 5.2 & $493^{* *}$ & 5.3 \\
\hline Protein $(\mathrm{kg})$ & 435 & 3.1 & $425^{* *}$ & 2.8 & $418^{* *}$ & 3.9 & 432 & 4.0 \\
\hline Fat + protein $(\mathrm{kg})$ & 953 & 6.8 & $912^{* *}$ & 6.2 & $897 * *$ & 8.6 & $926^{*}$ & 8.8 \\
\hline
\end{tabular}

$\dagger$ Tendency for significant difference $(P \leq 0.10)$ from Holsteins.

*Significant difference $(P \leq 0.05)$ from Holsteins.

**Significant difference $(P \leq 0.01)$ from Holsteins.

group (crossbred or HO). The GLM procedure of SAS was used to perform the ANOVA, to obtain the least squares solutions, and to determine $P$-values for contrasts of breed groups.

\section{RESULTS AND DISCUSSION}

Results of the combined crossbred types within each of the first 2 generations of crossbreds are compared with their $\mathrm{HO}$ herdmates in addition to each breed type

Table 7. Least squares solutions and SE for age at calving and 305$\mathrm{d}$ production (actual basis, not mature equivalent) for Holstein-sired crossbreds compared with their Holstein herdmates for first lactation

\begin{tabular}{lcccccc}
\hline & \multicolumn{2}{c}{ Holstein } & & \multicolumn{3}{c}{$\begin{array}{c}\text { Holstein-sired } \\
\text { crossbred }\end{array}$} \\
\cline { 2 - 3 } \cline { 5 - 6 } Trait & Mean & SE & & Mean & SE \\
\hline Cows (n) & \multicolumn{2}{c}{417} & & & 257 \\
Age at calving (mo) & 22.9 & 0.09 & & $22.6^{*}$ & 0.11 \\
Milk (kg) & 12,254 & 89 & & $11,665^{* *}$ & 111 \\
Fat (kg) & 450 & 3.2 & & 446 & 3.9 \\
Protein (kg) & 373 & 2.4 & & 367 & 2.9 \\
Fat + protein $(\mathrm{kg})$ & 824 & 5.1 & & 813 & 6.4 \\
\hline
\end{tabular}

*Significant difference $(P \leq 0.05)$ from Holsteins.

** Significant difference $(P \leq 0.01)$ from Holsteins. separately for the 2-breed and 3-breed crossbreds. The combination of both the $\mathrm{VR} \times \mathrm{HO}$ and $\mathrm{MO} \times \mathrm{HO}$ crossbreds and, likewise, the $\mathrm{VR} \times \mathrm{MO} / \mathrm{HO}$ and $\mathrm{MO}$ $\times \mathrm{VR} / \mathrm{HO}$ crossbreds offered a clearer perspective of the experience of the 7 herds during each generation of the 3-breed rotation. In practice, many herds in the United States initiate 3-breed rotational crossbreeding with the VR, MO, and HO breeds such that both types of 2-breed and 3-breed cattle are in the same herds.

\section{Fertility}

2-Breed Crossbreds and HO Herdmates. The fixed effects of lactation number, HYS nested within lactation number, breed group, and breed type were highly significant $(P \leq 0.01)$ for FSCR, overall CR, times bred, and DO, except breed type only tended ( $P$ $=0.08$ ) to be significant for FSCR for the comparison of the $\mathrm{VR} \times \mathrm{HO}$ and $\mathrm{MO} \times \mathrm{HO}$ crossbreds with their HO herdmates. The interaction of lactation number with breed type was significant $(P \leq 0.05)$ for only FSCR. Across all lactations, the 2-breed crossbred cows were superior $(P \leq 0.01)$ for all of the fertility traits. During first lactation, the 2-breed crossbreds had $+7 \%$ and $+6 \%$ higher $(P \leq 0.01)$ FSCR and overall $\mathrm{CR}$, respectively (Table 2 ). The higher $\mathrm{CR}$ of the 2-breed 
crossbreds resulted in fewer times bred $(-0.22)$ and lower DO $(-9 \mathrm{~d})$ for the 2-breed crossbreds compared with their $\mathrm{HO}$ herdmates during first lactation. In second and third lactations, the advantage of the 2-breed crossbred cows compared with their HO herdmates became even larger than the breed group difference during first lactation (Table 2). For FSCR, the advantage $(P$ $\leq 0.01$ ) of the 2-breed crossbred cows compared with their $\mathrm{HO}$ herdmates increased from $+7 \%$ during first lactation to $+9 \%$ during second lactation. Likewise, for DO, the advantage $(P \leq 0.01)$ of the 2 -breed crossbreds compared with their HO herdmates increased from -9 $\mathrm{d}$ lower during first lactation to $-17 \mathrm{~d}$ lower in second lactation. In third lactation, the 2-breed crossbreds had significantly $(P \leq 0.01)$ fewer DO $(-19 \mathrm{~d})$ compared with their HO herdmates.

Across their 3 lactations, the 2-breed crossbreds had a weighted least squares solution for FSCR that was $+7.3 \%$ higher than their HO herdmates (Table 2). The $\mathrm{HO}$ herdmates of the 2-breed crossbreds had a weighted least squares solution for DO of $134 \mathrm{~d}$ across lactations, which was superior to the 148 DO of DHI herds from a large sample of dairy herds in the United States (Dairy Records Management System, 2019). However, the VR $\times$ HO crossbreds had $-8 \mathrm{~d}$ fewer DO and the MO $\times$ HO crossbreds had $-17 \mathrm{~d}$ fewer DO than their HO herdmates across the 3 lactation numbers. Similar to our results, Clasen et al. (2019) observed -9 to $-16 \mathrm{~d}$ fewer DO in first lactation and -8 to $-11 \mathrm{~d}$ fewer DO in second lactation for $\mathrm{VR} \times \mathrm{HO}$ crossbreds compared with HO herdmates in a large Danish study.

The deviation for $\mathrm{DO}$ of the $\mathrm{MO} \times \mathrm{HO}$ crossbreds from their $\mathrm{HO}$ herdmates in the current study was similar to that observed by Heins and Hansen (2012) in a California field study in which $\mathrm{MO} \times \mathrm{HO}$ crossbreds had -16 to $-24 \mathrm{~d}$ fewer DO compared with their HO herdmates during first to third lactation. However, results in that study (Heins and Hansen, 2012) for Scandinavian Red $\times$ HO crossbreds $(-11$ d to -14 d) compared with their HO herdmates were larger than the -4 to $-11 \mathrm{~d}$ advantage of the $\mathrm{VR} \times \mathrm{HO}$ crossbreds compared with their HO herdmates in this study. An explanation may be the fat plus protein production $(\mathrm{kg})$ of the $\mathrm{VR} \times$ $\mathrm{HO}$ crossbreds in this study was similar to their HO herdmates, whereas fat plus protein production $(\mathrm{kg})$ of the Scandinavian Red $\times \mathrm{HO}$ crossbreds in the study of Heins and Hansen (2012) was significantly lower than their HO herdmates in multiparous lactations. Because production and fertility usually have a negative relationship (Walsh et al., 2011), a larger advantage for fertility was expected from the Scandinavian Red $\times$ HO crossbreds in the California study compared with their $\mathrm{HO}$ herdmates than the difference of $\mathrm{VR} \times \mathrm{HO}$ crossbreds and their $\mathrm{HO}$ herdmates observed in the current study.

3-Breed Crossbreds and HO Herdmates. The independent variables of lactation number. HYS nested within lactation number, and breed group were significant $(P \leq 0.05)$ for all 4 fertility traits of the 3-breed crossbreds compared with their HO herdmates. However, breed type was not significant $(P \geq 0.18)$, which reflected the small differences between the $\mathrm{VR} \times \mathrm{MO} /$ $\mathrm{HO}$ and $\mathrm{MO} \times \mathrm{VR} / \mathrm{HO}$ crossbreds across lactations for FSCR, overall CR, times bred, and DO. In fact, the VR $\times \mathrm{MO} / \mathrm{HO}$ and $\mathrm{MO} \times \mathrm{VR} / \mathrm{HO}$ crossbreds did not differ $(P>0.10)$ for any contrast of any of the 4 fertility traits within lactations. The interactions of lactation number with breed group and with breed type were not significant $(P>0.25)$ for any of the fertility traits of 3 -breed crossbreds and their HO herdmates.

When combined, the 2 types of 3 -breed crossbreds had large advantages $(P \leq 0.01)$ over their HO herdmates for every fertility trait in each lactation number. The 3 -breed crossbreds were $+9 \%$ to $+10 \%$ higher for FSCR and had -15 to $-20 \mathrm{~d}$ fewer DO compared with their HO herdmates, and these were larger differences than the 2-breed crossbreds compared with their HO herdmates. Interestingly, the HO herdmates of the 3-breed crossbreds had improvement of their least squares solutions for several of the fertility measures compared with the HO herdmates of the 2-breed crossbreds. For example, the FSCR of the HO herdmates of the crossbreds improved $+6 \%,+6 \%$, and $+5 \%$ during first, second, and third lactation, respectively, between the 2 generations of $\mathrm{HO}$ cows (Tables 2 and 3). Therefore, both the 3-breed crossbreds and their HO herdmates were likely affected by improved facilities, improved fertility management, and reduced use of bST, because all breed types experienced improved fertility from first to second generation in this study.

The weighted least squares solution for DO was -16.5 d lower for the combined 3-breed crossbreds averaged across the 3 lactations and was almost 3 wk lower for the third-lactation 3-breed crossbred cows compared with their HO herdmates. These results agree with those found by Malchiodi et al. (2014), who observed $\mathrm{MO} \times \mathrm{VR} / \mathrm{HO}$ crossbreds in first lactation had greater odds of conception at first insemination and had fewer times bred compared with their HO herdmates. However, that study was performed in commercial Italian dairy herds and reported a more extreme result of -39 $\mathrm{d}$ fewer $\mathrm{DO}$ for the $\mathrm{MO} \times \mathrm{VR} / \mathrm{HO}$ crossbreds compared with their HO herdmates during first lactation (Malchiodi et al., 2014).

HO-Sired Crossbreds and HO Herdmates. The HYS explained significant $(P \leq 0.02)$ variation for 
FSCR, overall CR, times bred, and DO of the HOsired crossbreds and their HO herdmates. The HOsired crossbreds did not differ $(P \geq 0.12)$ from their HO herdmates for any of the fertility traits during first lactation (Table 4). Numerically, however, the HO-sired crossbreds had $+3 \%$ higher FSCR and $-7 \mathrm{~d}$ fewer DO compared with their HO herdmates. An explanation for the nonsignificant results (Table 4) was the substantially smaller sample size available for the third generation of crossbreds and their HO herdmates compared with those of the first and second generations (Tables 2 and 3) that were analyzed in this study. Therefore, the standard errors of the least squares solutions were as much as double those for the first-lactation cows from the previous 2 generations.

The HO-sired crossbreds (with a mean of five-eighths HO content) and their HO herdmates both had a majority HO content. However, improved fertility was anticipated for the HO-sired crossbreds over their $\mathrm{HO}$ herdmates, because the heterosis of the HO-sired crossbreds averaged $75 \%$ of the full heterosis experienced during the first and second generations of crossbreds in a 3-breed rotation. Moreover, the inbreeding depression among the HO-sired crossbreds was trivial, whereas some inbreeding depression for fertility was expected for their HO herdmates. Other research on HO-sired crossbreds from a 3-breed rotation is sparse; however, Heins et al. (2014) compared small numbers of HOsired crossbreds from MO $\times$ Jersey/HO and Jersey $\times$ $\mathrm{MO} / \mathrm{HO}$ dams with their $\mathrm{HO}$ herdmates in a seasonal grazing herd and found an advantage of $-25 \mathrm{~d}$ fewer DO for the HO-sired crossbreds compared with their HO herdmates during first lactation.

Improvements in fertility are often a primary reason stated by dairy producers for crossbreeding (Weigel and Barlass, 2003), and high-input dairy herds benefit from crossbreeding at least as much for fertility as their lower-input counterparts (Clasen et al., 2019). Although the 7 herds in the current study surpassed United States benchmarks for satisfactory fertility of the HO cows, the 2-breed and 3-breed crossbreds had significantly improved fertility compared with their $\mathrm{HO}$ herdmates. The effect of a high degree of heterosis for fertility relative to other traits (Sørensen et al., 2008) likely had a large effect on the fertility advantage of the crossbreds compared with their HO herdmates; however, the additive genetic effects of the VR and MO breeds were likely contributors, too. Both the VR and MO breeds have applied selection for fertility for several decades longer than has the HO breed.

Body condition score is a strong predictor of fertility (Tiezzi et al., 2013), but depressed cow health has a positive relationship with low BCS, and this may exacerbate poor fertility. Both VR-sired and MO-sired crossbreds usually have higher BCS than HO cows (Walsh et al., 2008; Hazel et al., 2017a). For selection emphasis alongside production over time, the VR breed ignored the body condition of cows, and the MO breed selected for higher BCS via 2 muscularity traits. Conversely, the HO breed has selected for lower BCS over time (Hansen, 2000).

\section{Age at Calving and 305-d Production}

2-Breed Crossbreds and HO Herdmates. The fixed effect of HYS of calving was highly significant in the analyses of age at first, second, and third calving for the 2-breed crossbreds and their HO herdmates. The mean age at first, second, and third calving was low for these 7 herds, and 6 of the herds aimed to have heifers calve a first time by 22 to 23 mo of age. However, one herd preferred to calve heifers for first lactation between 27 and $28 \mathrm{mo}$, and that herd also had older age at second and third calving by 5 to 6 mo compared with the 6 herds with younger age at first calving. The age at calving did not differ for the 2-breed crossbreds compared with their HO herdmates during first and second lactation; however, the 2-breed crossbreds combined had -0.4 mo earlier age at third calving than their HO herdmates (Table 5). It is important to realize the differences for ages of calving of the breed types do not accurately reflect differences for fertility because many cows that did not conceive early in lactation and all cows that did not become pregnant were not included in the analysis for subsequent lactations.

The fixed effects of lactation number, HYS nested within lactation number, breed group, and breed type were all highly significant for 305-d milk, fat, protein, and fat plus protein production $(\mathrm{kg})$ for the 2-breed crossbreds and their HO herdmates, except breed group and breed type did not differ $(P \geq 0.14)$ for fat production $(\mathrm{kg})$. The interactions of lactation number with breed group and lactation number with breed type were significant $(P \leq 0.05)$ for $305-\mathrm{d}$ milk production $(\mathrm{kg})$. During first lactation, the 305-d fat, protein, and fat plus protein production $(\mathrm{kg})$ was $+2 \%$ higher $(P \leq 0.01)$ for the 2-breed crossbreds compared with their HO herdmates, and the difference was due to the significantly $(P \leq 0.01)$ higher fat and protein production $(\mathrm{kg})$ of the $\mathrm{MO} \times \mathrm{HO}$ first-lactation crossbreds (Table 5). The VR $\times$ HO crossbreds were numerically $(+1 \%)$ higher, but did not differ $(P=0.14)$ from their HO herdmates, for fat plus protein production $(\mathrm{kg})$ during first lactation. For second and third lactation, the 2-breed crossbreds had significantly $(P \leq 0.05)$ higher protein production $(+1 \%$ and $+1 \%$, respectively) compared with their HO herdmates, and the difference was attributed to the 
$+3 \%$ higher $(P \leq 0.01)$ protein production $(\mathrm{kg})$ of the $\mathrm{MO} \times \mathrm{HO}$ crossbreds. The $\mathrm{VR} \times \mathrm{HO}$ crossbreds had no loss $(P>0.10)$ of fat plus protein production $(\mathrm{kg})$ compared with their HO herdmates during second or third lactation (Table 5).

Results in the current study were somewhat different than those of Heins and Hansen (2012) in a California field study. They reported Scandinavian Red $\times \mathrm{HO}$ crossbreds were similar in first lactation and lower $(P$ $<0.01)$ in second and third lactation compared with their HO herdmates for fat plus protein production $(\mathrm{kg})$. Furthermore, the $\mathrm{MO} \times \mathrm{HO}$ crossbreds in the California study had less $(P<0.05)$ fat plus protein production $(\mathrm{kg})$ than their $\mathrm{HO}$ herdmates during each of their first 3 lactations (Heins and Hansen, 2012). In an Italian commercial herd (Malchiodi et al., 2011), $\mathrm{VR} \times \mathrm{HO}$ crossbreds had less daily milk volume $(\mathrm{kg})$ with $-4 \%$ less protein production $(\mathrm{kg})$, but similar fat production $(\mathrm{kg})$ compared with their $\mathrm{HO}$ herdmates during first and second lactation. Walsh et al. (2008) studied $\mathrm{MO} \times \mathrm{HO}$ crossbreds and their $\mathrm{HO}$ herdmates in an institutional grazing herd and found $\mathrm{MO} \times \mathrm{HO}$ crossbreds had $-3 \%$ lower fat production $(\mathrm{kg})$ across 5 lactations but were not different for protein production $(\mathrm{kg})$ from their HO herdmates.

An explanation for the different results for crossbreds in the current study compared with other studies was the cows in these 7 herds resulted from a balanced design in which dams of both crossbred and $\mathrm{HO}$ cows were paired by sire and phenotypic production. This approach may be atypical of herds that endeavor to compare their crossbred and $\mathrm{HO}$ cows because commercial dairy producers may often inseminate their poor-fertility or low-producing $\mathrm{HO}$ cows with semen from non-HO bulls.

The fluid milk volume $(\mathrm{kg})$ was lower $(P \leq 0.01)$ for the VR $\times \mathrm{HO}$ crossbreds compared with their $\mathrm{HO}$ herdmates in this study during each of the first 3 lactations (Table 5), but the MO $\times \mathrm{HO}$ crossbreds did not differ $(P>0.10)$ from their HO herdmates for fluid milk volume $(\mathrm{kg})$ during any of the 3 lactations. The lower milk volume of the combined crossbred cows (Table 5) should be regarded as an economic advantage for dairy producers whose milk is used for manufacturing. The vast majority of milk sold in the United States provides little, if any, financial payment for the fluid that carries the solids. High fluid volume $(\mathrm{kg})$ without similarly high fat and protein production $(\mathrm{kg})$ is a detriment to production revenue because it costs more to cool, store, and transport the fluid carrier. This is the justification for the negative weight on milk volume $(\mathrm{kg})$ in the Lifetime Net Merit selection index (VanRaden et al., 2018) in the United States. Therefore, the lower milk volume $(\mathrm{kg})$ of the 2-breed crossbreds along with similar or higher fat plus protein production (Table 5) suggested increased profitability for the 2-breed crossbreds compared with their HO herdmates in this study. The percentages of fat and protein were calculated subsequent to the analyses of milk, fat, and protein production $(\mathrm{kg})$ and were $+0.10 \%$ to $+0.14 \%$ higher for fat percentage and $+0.12 \%$ to $+0.13 \%$ higher for protein percentage for the 3 lactations of 2-breed crossbreds compared with their HO herdmates.

3-Breed Crossbreds and HO Herdmates. The fixed effects of HYS of calving nested within lactation number and breed group were highly significant $(P \leq$ 0.01 ) in the analyses of age at first, second, and third calving for the 3-breed crossbreds and their HO herdmates. Furthermore, breed type was significant $(P \leq$ 0.05 ) for age at first calving of the 3-breed crossbreds and their HO herdmates. Contrary to the results for the 2-breed crossbreds, the 3-breed crossbreds had significantly $(P \leq 0.01)$ younger ages at first, second, and third calving than their $\mathrm{HO}$ herdmates. The magnitude of the difference was $-12,-21$, and $-49 \mathrm{~d}$ earlier for the 3 successive lactations, respectively. The 3 -breed crossbreds had even larger advantages for fertility compared with their HO herdmates than did the 2-breed crossbreds, and this larger difference was apparent in the age at calving results for the cows included in the analysis of 305-d production.

The independent variables of lactation number, HYS nested within lactation number, breed group, and breed type were all highly significant $(P \leq 0.01)$ for the analysis of milk, fat, protein, and fat plus protein production $(\mathrm{kg})$. The interaction of lactation number with breed group tended $(P=0.06)$ to be significant for fat production $(\mathrm{kg})$ of the 3-breed crossbreds and their HO herdmates. The combined 3-breed crossbreds had lower $(P \leq 0.01)$ fat plus protein production $(\mathrm{kg})$ than their HO herdmates during first $(-4 \%)$, second $(-3 \%)$, and third $(-4 \%)$ lactation (Table 6$)$. The MO $\times \mathrm{VR} / \mathrm{HO}$ crossbreds were $2 \%$ to $3 \%$ higher in each lactation for fat plus protein production $(\mathrm{kg})$ than the $\mathrm{VR} \times \mathrm{MO} / \mathrm{HO}$ crossbreds, which coincides with the numerically higher production of the $\mathrm{MO} \times \mathrm{HO}$ crossbreds compared with the VR $\times \mathrm{HO}$ crossbreds in the first generation of this study. The 3-breed crossbreds had numerically higher percentages of fat $(+0.12 \%$ to $+0.20 \%)$ and protein $(+0.19 \%$ to $+0.22 \%)$ than their HO herdmates during their first 3 lactations. A recent study in France (Balandraud et al., 2019) reported MO cows had higher fat percentage $(+0.11 \%)$ and protein percentage $(+0.13 \%)$ than HO cows in silage-fed herds. Our results were similar to those reported by Malchiodi et al. (2011), who found $\mathrm{MO} \times \mathrm{VR} / \mathrm{HO}$ crossbreds produced $-3 \%$ lower fat plus protein production $(\mathrm{kg})$ than their HO herdmates during first and second lacta- 
tion. In that study, the difference resulted from the $-6 \%$ lower fat production $(\mathrm{kg})$ of the $\mathrm{MO} \times \mathrm{VR} / \mathrm{HO}$ crossbreds compared with their HO herdmates because the $\mathrm{MO} \times \mathrm{VR} / \mathrm{HO}$ crossbreds did not differ from their $\mathrm{HO}$ herdmates for protein production $(\mathrm{kg})$.

The lower solids production $(\mathrm{kg})$ of the 3 -breed crossbreds was not surprising because the 305 -d production was not adjusted for the $-16.5 \mathrm{~d}$ fewer DO of the 3-breed crossbreds compared with their HO herdmates. The BP accounted for the DO in their previous lactation for cows in their second and third lactations. However, no adjustment was made for current DO, and the DO in current lactation affects 305-d production (Penasa et al., 2016). Adjusting production for DO is difficult because the cause-and-effect relationship between the 2 traits is ambiguous. Furthermore, many data for each crossbred breed type and their HO herdmates would be required to determine the appropriate adjustment factors for current DO.

The 305-d production of cows may adequately measure the potential of a breed type during a lactation of fixed length. However, in this study, the 305-d production was likely discordant with the true kilograms of solids produced by each cow during their lifetimes because BP projected the $305-\mathrm{d}$ fat plus protein $(\mathrm{kg})$ to $305 \mathrm{~d}$ for cows with lactations shorter than $305 \mathrm{~d}$. A chi-square test revealed fewer $(P \leq 0.01)$ of the 3 -breed multiparous crossbreds (18\%) were culled or died before 305 DIM than their HO multiparous herdmates (23\%). Therefore, the HO herdmates of the 3-breed crossbreds benefited from the projection by BP of more unrealized 305-d fat plus protein production $(\mathrm{kg})$ compared with less unrealized 305-d fat plus protein production projected by BP for the 3-breed crossbreds.

HO-Sired Crossbreds and HO Herdmates. The fixed effect of HYS of first calving was significant $(P \leq$ 0.05 ) for the analysis of age at first calving of HO-sired crossbreds and their $\mathrm{HO}$ herdmates. The HO-sired crossbreds had the lowest average age at first calving among the 3 generations of crossbreds studied. The HO-sired crossbreds calved at 22.6 mo of age, which was -9 d younger $(P \leq 0.05)$ than their HO herdmates (Table 7 ). Some dairy producers have expressed concern about age at first calving for crossbreds that contain MO. The MO heifers in France calve for a first time at ages that are typically older than heifers of any breed in the United States; however, the reason is not because of limitations on growth, maturity, or fertility, but rather, a different production system. The results of this study across the 3 generations of crossbreds suggests crossbred heifers sired by VR, MO, or HO bulls should be managed identically to pure HO heifers with regard to age at first breeding and first calving.
The HYS of first calving was a significant $(P \leq$ 0.01 ) fixed effect for the analysis of milk, fat, protein, and fat plus protein production $(\mathrm{kg})$ for the HO-sired crossbreds and their HO herdmates. The HO-sired crossbreds had lower $(P \leq 0.01)$ fluid milk volume than their HO herdmates during first lactation; however, no difference was observed for fat, protein, or fat plus protein production $(\mathrm{kg})$ between breed groups (Table 7 ). Similar to the 2 previous generations of crossbreds, the HO-sired crossbreds had numerically higher fat content $(+0.15 \%)$ and higher protein content $(+0.10 \%)$ than their HO herdmates during first lactation.

The sale of milk represents the majority of revenue for a dairy enterprise, but the production of cows may be less important for profitability than the combined effect of the expenses incurred on dairy farms (MacDonald et al., 2007; Heins et al., 2012). A more comprehensive analysis of economic sustainability must include the expenses for feed, health care of cows, fertility, replacement, and labor incurred. For this reason, genetic selection of dairy cattle has moved away from emphasizing mostly milk production (Miglior et al., 2017).

The results for production of cows is incomplete without consideration of the feed required to produce milk solids, and feed efficiency should be a major consideration for choice of a breeding plan by dairy producers. Shonka-Martin et al. (2019) documented improved feed efficiency and income over feed cost for various generations of 3-breed crosses of the VR, MO, and HO breeds compared with their HO herdmates. In that study, the crossbred cows had an advantage for income over feed cost of $+\$ 0.51$ per day compared with their HO herdmates. Therefore, the production of crossbred and $\mathrm{HO}$ cows should be assessed alongside feed efficiency.

\section{Implications for the Industry}

Breed composition of the global dairy cattle population has shifted somewhat away from the HO breed in recent years because dairy producers are concerned about the deterioration of fertility, health, and longevity of $\mathrm{HO}$ cows. Furthermore, dairy producers now place increased emphasis on minimizing the major expenses for cows (e.g., feed intake, repeat inseminations, health treatments, and premature replacement). Data from this study documented that 2-breed (-12.0 d fewer DO) and 3-breed crossbred $(-16.5 \mathrm{~d}$ fewer DO) cows were superior to their HO herdmates for fertility during their first 3 lactations. The advantages for fertility of the crossbreds compared with their HO herdmates reduced the cost of inseminations, but a larger effect should be the longer herd life of the crossbred cows compared with their HO herdmates resulting from the advantages 
for fertility. The 305-d production of milk solids $(\mathrm{kg})$ was $1 \%$ to $2 \%$ higher for the 2 -breed crossbreds, $3 \%$ to $4 \%$ lower for the 3-breed crossbreds, and similar for the HO-sired crossbreds compared with their respective HO herdmates in these high-performance herds. However, the comparison of production via 305-d lactational records may be misleading because some $305-\mathrm{d}$ production was projected and not realized as income for dairy producers. Also, the advantages for fertility resulted in the crossbreds returning to peak production sooner than their HO herdmates at subsequent calving.

Historically, because of the global predominance of the high-producing HO breed, some dairy producers have been concerned that crossbred cows will have lower fat plus protein production $(\mathrm{kg})$ than $\mathrm{HO}$ cows. However, this large and carefully designed study documented little, if any, loss of fat plus protein production $(\mathrm{kg})$ for $\mathrm{VR}, \mathrm{MO}$, and HO 3-breed crossbreds compared with their HO herdmates, especially when keeping in mind the $305-\mathrm{d}$ production $(\mathrm{kg})$ of cows in this study was unadjusted for DO during current lactations. Furthermore, the results of this study documented the 3 breeds of VR, MO, and HO appear to complement each other well for rotational crossbreeding and to be well suited for milk production in high-performance dairy herds.

\section{ACKNOWLEDGMENTS}

The authors express gratitude to the dairy producers and managers of the 7 dairy herds for their participation in this study and for providing data on the cows in their herds. The authors also thank Minnesota Select Sires Co-op Inc. (St. Cloud, MN) for its contributions of mating individual heifers and cows with AI bulls. Funding for this study was provided by Coopex Montbéliarde (Roulans, France), Viking Genetics (Randers, Denmark), Creative Genetics of California (Oakdale, CA), Select Sires, Inc. (Plain City, OH), and Minnesota Select Sires Co-op Inc. The authors have not stated any conflicts of interest.

\section{REFERENCES}

Balandraud, N., C. Mosnier, L. Delaby, F. Dubief, J. Goron, B. Martin, D. Pomiès, and A. Cassard. 2019. Holstein ou Montbéliarde: des differences phénotypiques aux consequences économiques à l'échelle de l'exploitation. INRA Prod. Anim. 31:337-352. https:// doi.org/10.20870/productions-animales.2018.31.4.2394.

Buckley, F., N. Lopez-Villalobos, and B. J. Heins. 2014. Crossbreeding: Implications for dairy cow fertility and survival. Animal 8(s1):122-133. https://doi.org/10.1017/S1751731114000901.

CDCB. 2019. Trend in daughter preg rate for Holstein or Red \& White. Accessed Dec 16, 2019. https://queries.uscdcb.com/eval/ summary/trend.cfm?R_Menu=HO.d\#StartBody.

Clasen, J. B., A. Fogh, and M. Kargo. 2019. Differences between performance of $\mathrm{F}_{1}$ crossbreds and Holsteins at different production levels. J. Dairy Sci. 102:436-441. https://doi.org/10.3168/jds.2018 $-14975$.

Cole, J. B., D. J. Null, and P. M. VanRaden. 2009. Best prediction of yields for long lactations. J. Dairy Sci. 92:1796-1810. https://doi .org/10.3168/jds.2007-0976.

Dairy Records Management System. 2019. DairyMetrics Report. Accessed Oct. 21, 2019. http://retro.drms.org/DairyMetricsRun .aspx.

Dezetter, C., H. Leclerc, S. Mattalia, A. Barbat, D. Boichard, and V. Ducrocq. 2015. Inbreeding and crossbreeding parameters for production and fertility traits in Holstein, Montbéliarde, and Normande cows. J. Dairy Sci. 98:4904-4913. https://doi.org/10.3168/ jds.2014-8386.

Falconer, D. S., and T. F. C. Mackay. 1996. Introduction to Quantitative Genetics. 4th ed. Longman House, Harlow, Essex, UK.

Fleming, A., C. F. Baes, A. A. A. Martin, T. C. S. Chud, F. Malchiodi, L. F. Brito, and F. Miglior. 2019. Symposium review: The choice and collection of new relevant phenotypes for fertility selection. J. Dairy Sci. 102:3722-3734. https://doi.org/10.3168/jds.2018-15470.

Hansen, L. B. 2000. Symposium: Selection for milk yield. Consequences of selection for milk yield from a geneticist's viewpoint. J. Dairy Sci. 83:1145-1150. https://doi.org/10.3168/jds.S0022 $-0302(00) 74980-0$.

Hazel, A. R., B. J. Heins, and L. B. Hansen. 2017a. Fertility, survival, and conformation of Montbéliarde $\times$ Holstein and Viking Red $\times$ Holstein crossbred cows compared with pure Holstein cows during first lactation in 8 commercial dairy herds. J. Dairy Sci. 100:94479458. https://doi.org/10.3168/jds.2017-12824.

Hazel, A. R., B. J. Heins, and L. B. Hansen. 2017b. Production and calving traits of Montbéliarde $\times$ Holstein and Viking Red $\times$ Holstein cows compared with pure Holstein cows during first lactation in 8 commercial dairy herds. J. Dairy Sci. 100:4139-4149. https:// doi.org/10.3168/jds.2016-11860.

Heins, B. J., and L. B. Hansen. 2012. Short communication: Fertility, somatic cell score, and production of Normande $\times$ Holstein, Montbéliarde $\times$ Holstein, and Scandinavian Red $\times$ Holstein crossbreds versus pure Holsteins during their first 5 lactations. J. Dairy Sci. 95:918-924. https://doi.org/10.3168/jds.2011-4523.

Heins, B. J., L. B. Hansen, and A. De Vries. 2012. Survival, lifetime production, and profitability of Normande $\times$ Holstein, Montbéliarde $\times$ Holstein, and Scandinavian Red $\times$ Holstein crossbreds versus pure Holsteins. J. Dairy Sci. 95:1011-1021. https://doi.org/ $10.3168 /$ jds. $2011-4525$

Heins, B. J., A. R. Hazel, and L. B. Hansen. 2014. Fertility and production of 3-breed and third generation Holstein-sired crossbreds compared to pure Holstein cows in a seasonal pasture production system. Accessed Jun. 19, 2020. http://www.wcgalp.org/system/ files/proceedings/2014/fertility-and-production-3-breed-and-third -generation-holstein-sired-crossbreds-compared-pure.pdf.

Inchaisri, C., R. Jorritsma, P. L. A. M. Vos, G. C. van der Weijden, and H. Hogeveen. 2010. Economic consequences of reproductive performance in dairy cattle. Theriogenology 74:835-846. https:// doi.org/10.1016/j.theriogenology.2010.04.008.

Jönsson, R. 2015. Estimation of heterosis and performance of crossbred Swedish dairy cows. MS Thesis. Department of Animal Breeding and Genetics, Swedish University of Agricultural Sciences, Uppsala.

MacDonald, J. M., E. J. O'Donoghue, W. D. McBride, R. F. Nehring, C. L. Sandretto, and R. Mosheim. 2007. Economic Research Report ERR-47: Profits, costs, and the changing structure of dairy farming. Accessed Oct. 21, 2019. http://ers.usda.gov/publications/pub -details $/$ ?pubid $=45870$.

Malchiodi, F., A. Cecchinato, and G. Bittante. 2014. Fertility traits of purebred Holsteins and 2- and 3-breed crossbred heifers and cows obtained from Swedish Red, Montbéliarde, and Brown Swiss sires. J. Dairy Sci. 97:7916-7926. https://doi.org/10.3168/jds.2014 $-8156$.

Malchiodi, F., M. Penasa, F. Tiezzi, and G. Bittante. 2011. Milk yield traits, somatic cell score, milking time and age at calving of pure Holstein versus crossbred cows. ACS Agric. Conspec. Sci. 76:259261. 
Miglior, F., A. Fleming, F. Malchiodi, L. F. Brito, P. Martin, and C. F. Baes. 2017. A 100-year review: Identification and genetic selection of economically important traits in dairy cattle. J. Dairy Sci. 100:10251-10271. https://doi.org/10.3168/jds.2017-12968.

Penasa, M., M. De Marchi, and M. Cassandro. 2016. Short communication: Effects of pregnancy on milk yield, composition traits, and coagulation properties of Holstein cows. J. Dairy Sci. 99:48644869. https://doi.org/10.3168/jds.2015-10168.

Shibru, D. 2016. Review on: Effect of using recombinant bovine somatotropin (rbST) hormone on dairy cattle production. Global J. Sci. Frontier Res. 16:19-30.

Shonka-Martin, B. N., B. J. Heins, and L. B. Hansen. 2019. Threebreed rotational crossbreds of Montbéliarde, Viking Red, and Holstein compared with Holstein cows for feed efficiency, income over feed cost, and residual feed intake. J. Dairy Sci. 102:3661-3673. https://doi.org/10.3168/jds.2018-15682.

Sørensen, M. K., E. Norberg, J. Pedersen, and L. G. Christensen. 2008. Invited review: Crossbreeding in dairy cattle: A Danish perspective. J. Dairy Sci. 91:4116-4128. https://doi.org/10.3168/jds.2008 $-1273$.

Tiezzi, F., C. Maltecca, A. Cecchinato, M. Penasa, and G. Bittante. 2013. Thin and fat cows, and the nonlinear genetic relationship between body condition score and fertility. J. Dairy Sci. 96:67306741. https://doi.org/10.3168/jds.2013-6863.

VanRaden, P. M., J. B. Cole, and K. L. Parker Gaddis. 2018. AIP Research Report NM\$7: Net merit as a measure of lifetime profit:
2018 revision. Accessed Oct. 21, 2019. http://aipl.arsusda.gov/ reference/nmcalc-2018.htm.

VanRaden, P. M., A. H. Sanders, M. E. Tooker, R. H. Miller, H. D. Norman, M. T. Kuhn, and G. R. Wiggans. 2004. Development of a national genetic evaluation for cow fertility. J. Dairy Sci. 87:22852292. https://doi.org/10.3168/jds.S0022-0302(04)70049-1.

Walsh, S., F. Buckley, K. Pierce, N. Byrne, J. Patton, and P. Dillon. 2008. Effects of breed and feeding system on milk production body weight, body condition score, reproductive performance, and postpartum ovarian function. J. Dairy Sci. 91:4401-4413. https:// doi.org/10.3168/jds.2007-0818.

Walsh, S. W., E. J. Williams, and A. C. O. Evans. 2011. A review of the causes of poor fertility in high milk producing dairy cows. Anim. Reprod. Sci. 123:127-138. https://doi.org/10.1016/j .anireprosci.2010.12.001.

Weigel, K. A., and K. A. Barlass. 2003. Results of a producer survey regarding crossbreeding on US dairy farms. J. Dairy Sci. 86:4148 4154. https://doi.org/10.3168/jds.S0022-0302(03)74029-6.

\section{ORCIDS}

A. R. Hazel (1) https://orcid.org/0000-0002-1713-7834

B. J. Heins @ https://orcid.org/0000-0003-2186-9082

L. B. Hansen () https://orcid.org/0000-0002-2752-2736 